\title{
A conversation with Thomas (Tom) R. Belin- 2020 HPSS long-term excellence award winner
}

\author{
Ofer Harel ${ }^{1}$ (D) . Corwin Zigler ${ }^{2,3}$
}

Received: 15 June 2020 / Revised: 18 June 2020 / Accepted: 23 June 2020 / Published online: 1 July 2020 (c) Springer Science+Business Media, LLC, part of Springer Nature 2020

\begin{abstract}
At the 2020 International Conference on Health Policy Statistics held in San Diego, Thomas (Tom) R. Belin was awarded the Long-Term Excellence Award from the Health Policy Statistics Section of the American Statistical Association. Dr. Belin was exceptionally and uniquely qualified for this award. Highlights include his innovative statistical applications for health care research and his substantial contributions to the statistics and health policy communities through mentoring and service. In this interview, we asked Tom to share stories about his upbringing, schooling, and career phases to gain insights into his numerous achievements.
\end{abstract}

\section{Introduction}

The HPSS Long-Term Excellence Award recognizes significant contributions to the profession through mentoring and service. Candidates must be 15 or more years from their terminal degree on January 1, 2019. Tom met the eligibility criteria for the 2020 award as he earned his Ph.D. from the Harvard Department of Statistics in 1991. Having spent most of his career at UCLA, he serves as a Professor in the UCLA Department of Biostatistics and UCLA Department of Psychiatry and Biobehavioral Sciences. Along the way Dr. Belin served for a year as Acting Chair of the Department of Biostatistics and currently serves as the departmental Vice Chair. In research, Dr. Belin is internationally known for contributions to address practical problems in incomplete data. His methodological developments have often drawn on models incorporating latent structures and Bayesian estimation strategies, and in addition to health-related applications he has made lasting contributions to the literature on record linkage. He has secured grant funding from a wide range of government agencies and private foundations, and his 165 peer-reviewed publications, which include numerous contributions to top-tier journals, have garnered more than 15,000 citations. In leadership and service, after being a member of several organizing committees

Ofer Harel

ofer.harel@uconn.edu

1 Department of Statistics, University of Connecticut, Storrs, CT, USA

2 Department of Statistics and Data Sciences, The University of Texas at Austin, Austin, TX, USA

3 Department of Women's Health, Dell Medical School, The University of Texas At Austin, Austin, TX, USA 
for the flagship conference of HPSS, he co-chaired (with Arlene Ash) the 2005 installment of the ICHPS series, and he has subsequently been a member of ICHPS advisory boards. Through his many other service contributions in academia and professional societies, he is known as a bridge builder across institutions, communities, and individuals. Within the ASA, he has held leadership positions in the Survey Research Methods Section and the Biometrics Section, and he has served on both the ASA Census Advisory Committee and the ASA Committee on Professional Ethics. His professional contributions have been recognized by a diverse array of organizations (including the Oral and Maxillofacial Surgery Foundation, the American Academy of Child and Adolescent Psychiatry, the International Center of Mental Health Policy and Economics, and the UCLA Public Health Student Association), and recognition for his role in developing the Community Partners in Care project on dissemination of evidence-based strategies for depression in under-resourced communities included the Team Science Award from the Association for Clinical and Translational Science and American Federation for Medical Research, the Annual Award from the Community-Campus Partnership for Health, and the UCLA Community Program of the Year-Landmark Award (Belin et al. 2018; Shetty et al. 2008; Wells et al. 2013; Zima et al. 2010). Other recognition for his career contributions include being elected a Fellow of the ASA in 2004, receiving the Gertrude M. Cox Award from the Washington Statistical Society in 2005, and being the Lowell Reed Lecturer at the 2018 American Public Health Association annual meeting. The remainder of this paper draws on a recent conversation that Ofer Harel and Cory Zigler had with Tom that included plenty of lighthearted anecdotes while probing into the reasons for his success and development into the wonderful academic colleague we see today. Questions are in Roman font while Tom's responses are indicated by $\mathrm{TB}$ and are in italics.

\section{Early Life}

Can you summarize your upbringing? Where did you live as a child? What did your parents do and how did they influence you?

TB I had an idyllic childhood growing up in Des Moines, Iowa as the fourth of five kids of parents who were pillars of the community, benefiting as well from strong influences from other neighborhood families. There was always a lot of action in our home with so many kids in motion, and one reflection of the environment that you wouldn't see in today's society was a sign in our neighbor's backyard that served as the baseball or football field depending on the season where Rule Number 1 was "Everyone is welcome to play." We would walk to school at Clive Elementary, and in the winter, we could take a shortcut by walking across the creek when the ice was thick enough, although I learned the hard way that sometimes it was not! My parents met as undergraduates at the University of Michigan and stayed there for advanced degrees (business and law for my father, education for my mother). My father got a job with a law firm in Des Moines, and my mother was a teacher for a few years before my brother Jon came along. I was born in 1964, during the time my father was one of about a dozen lawyers who served as counsel to the Warren Commission. I recall first being aware of his role investigating the assassination of President Kennedy when we were on a family trip to Washington, DC when I was 8 years old, although I have an early memory from our home where we lived until I was 4 years old of seeing my father on television, which I assume was related to his Warren Commission work. He wrote two books on the subject-one published 
in 1973, the other in 1988-both of which influenced me greatly (Belin 1973, 1988). With the benefit of hindsight, I view his synthesis of the available evidence, including sometimes conflicting testimony and maddening investigation errors, as an illuminating illustration of Bayesian reasoning and causal inference in action. As it happens, I didn't read the first book cover-to-cover until much later; my initial attempt to do so as my free-reading book in 4th grade stalled after a couple of months.[I declared victory after reaching page 100 and returned to reading books like "Strange But True Baseball Stories" (Bisher 1966)]. When I was in 5th grade, we went door-to-door to support my mother's successful campaign for the local school board, and she was later appointed to the Board of Regents overseeing the state universities in Iowa. In a major turning point for our whole family and for me in particular, she died of breast cancer before reaching the age of 50, which happened during the summer between my sophomore and junior year of high school. Among her many legacies is a center in her name at the University of Iowa focused on gifted education and talent development, and one of the activities I have especially enjoyed is being a member of the center's Advisory Committee, where I often have an opportunity to share stories such as how she was willing to go along with building a new basketball arena for the University of Iowa but only if they converted their old arena into recreational athletic facilities benefiting all students.

What were your favorite and least favorite periods in school?

TB Math was definitely my strong subject. Often teachers didn't know quite what to do with me during their regular math lessons, but often I would be given a workbook of beyondgrade-level material, and one year I remember having regular opportunities to play "Score Four"-the three-dimensional tic-tac-toe game-which I think helped cultivate my intuition. I enjoyed school and would not say I had a least favorite subject, although when we started having multiple teachers at each grade level there were definitely some classes I enjoyed more because of the teachers.

What sports and/or other activities did you like?

TB I enjoyed playing sports from a young age, frequently playing basketball after school and tennis in the summer. Believe it or not, I twice won the "Mr. Basketball" award at our local Jewish Community Center, and I also played on my high-school tennis team. Following in my father's footsteps, I played the violin, although in high school I focused more on being on the school's debate team and student council. I had a series of great summercamp experiences at Camp Nebagamon in northern Wisconsin, and I've always relished the fact that what seemed to seal the deal in recruiting Cory [Zigler] to UCLA for graduate school was making the small-world connection in my role as our department's Admission and Financial Aid Chair that he went to camp there, too. (He had mentioned that he was from St. Louis, at which point I noted that I used to go to summer camp with a lot of kids from St. Louis, and we closed the loop moments later.) I also remember being very proud as a high-school senior to be one of the guys invited by our school's all-female, statechampion synchronized swimming team to participate in the spring synchronized swimming show. It always drew laughs after the team members had performed a series of creatively artistic and technically demanding routines to see a few dozen guys, mostly jocks, go through a few coordinated steps eventually leading to a show-stopping somersault. The girls coached us in early-morning practice sessions, where the routine was choreographed to a medley of "He's So Shy" transitioning to "Greased Lightning". I'd like to think I was 
regarded at least in part as a jock, but I assume I was invited more because of being on the debate team and involved in student government.

\section{Bachelor's degree-Stanford University}

Tell us a bit about how Stanford became the destination for your undergraduate studies and about your choice of major.

TB Both my older brother Jim (who majored in Political Science, graduating in 1980) and my sister Joy (who majored in History, graduating in 1983, and stayed for a masters degree in Education) had gone to Stanford, and I had enjoyed visiting them there, so once I got in it was an easy choice. That said, I had always viewed college as the stepping stone to law school, with my father as a role model, and originally, I was planning on being a History major. In fact, I remember finishing my freshman year thinking I would never take a math test again. But that summer, when I looked more closely at the History major requirements, there was a requirement beyond the history coursework that could be satisfied with either more of a command of a foreign language than I had or with a year's worth of statistics. Given what seemed to me to be a clear choice, I browsed through the catalog of possible majors to see whether there was an option to combine the math I had already taken with the statistics I was planning to take, and I came across the interdepartmental Mathematical and Computational Sciences major, which combined math, statistics, computer science, and operations research and which seemed just right. In meeting with the head of the program to be assigned an advisor, I was asked what I wanted to do going forward, and I remember saying that I didn't know but that I had thought about going to graduate school and had thought about teaching. The head of the program, Brad Efron, responded by saying something close to, "I think I'll keep you as one of my own advisees to keep an eye on you." I did not know who Brad Efron was at the time, but that was a life-changing, butterfly-wing-phenomenon moment for me. I would meet with him every quarter, and I also was mentored by Herb Solomon, who allowed me to take an independent-study course on statistics and the law with him after I had him as a professor in one of the core courses. Along the way, I had a number of interactions with Sally Morton (Winner of HPSS LongTerm Award 2018), who was then a Ph.D. student-when I had plans to go overseas to the London School of Economics, she offered insights from her experience of having studied there. Although I didn't get to know him until he later became a professor of mine (and teammate on the Harvard Statistics Department intramural basketball team), I also would say hi to Hal Stern, who like Sally was a Ph.D. student at Stanford when I was there.

Were you thinking of an academic career at this point? If not, what else were you thinking about?

TB When I declared the Mathematical and Computational Sciences major, I still thought that law school was an option. But my older brother, who graduated from law school at the end of my freshman year of college, didn't seem to be enjoying his work as a lawyer that much (he eventually went to business school and pursued portfolio-management work). I also liked working as a math tutor, and I found myself thinking that a direction aligned with the scientific coursework I was taking would be a better fit for me than a direction with less precision and more ambiguity. I could tell that there was an adjustment 
at first for my father when my plans solidified around graduate study in statistics, but as events unfolded he clearly enjoyed the new horizons I was pursuing.

\section{Graduate school-Harvard University}

You were part of an interesting cohort in graduate school. Can you describe what that was like and whether, all these years later, you still trace your particular professional path back to that cast of characters?

TB It was an amazing experience to be at Harvard during those years. The group that entered when I did included Andrew Gelman, Xiao-Li Meng, and Patricia Meehan (who sadly passed away in 2018). We were all different, but we complemented each other well. Among many other compelling figures, Chris Schmid and Joe Schafer were in the year ahead of us, Mark Glickman started the year after us (the same year Hal Stern joined the faculty), Alan Zaslavsky was formally enrolled at MIT but was generally around, and Raghu [T. E. Raghunathan] and John Carlin finished in the fall of our first year and stayed in the spring as instructors. [I was a teaching assistant for Raghu, and we all took Bayesian statistics with John Carlin, which sowed the seeds for the Gelman, Carlin, et al. "Bayesian Data Analysis" text (Gelman et al. 2013)]. Andrew, Xiao-Li, and I were all working with Don Rubin, but on different things. Andrew's Ph.D. thesis was on combining PETscan reconstructions in experiments (which vaulted him into the realm of MCMC computing), Xiao-Li was developing the SEM and ECM algorithms as extensions of EM, and I was working on calibrating false matches in computer matching related to census undercount estimation. It also happened that in the fall of 1986, when we started, the Red Sox were in the World Series, playing the N.Y. Mets in the series famous for their Game 6 collapse when the ball went through Bill Buckner's legs. Andrew and I went down to Kenmore Square to watch Game 3, the first in the series played in Boston, in one of the Fenway Park bars; the Mets hit a leadoff home run on their way to 4 runs in the top of the first inning and a wipeout victory, and more memorable than the game was the short course in human diversity we received from the people crammed into the same booth, such as from the woman who mixed tomato juice into her beer. Later I took Xiao-Li to his first baseball game, where I remember spending almost the entire time explaining the rules of the game. And then in the ninth inning, a rule was invoked that I knew existed but that I had never seen invoked before and have never seen invoked since, involving the one situation when someone can be put back in a game after having been taken out (namely, when a catcher is replaced and then the replacement gets injured, the original catcher can come back). I remember trying to explain to Xiao-Li not only the substance of the rule but also how rare it was for it to be invoked.

To put the timing of our graduate studies in perspective, the first edition of the Little and Rubin "Statistical Analysis with Missing Data" text came out in 1987 (Little and Rubin 2019), as did Rubin's “Multiple Imputation for Nonresponse in Surveys” (Rubin 2004). To put the experience of being a classmate of Andrew and Xiao-Li in further perspective, I'm reminded of an anecdote growing out of our Ph.D. qualifying exam. Drawing on Don having taught a class out of his newly published multiple-imputation text, I remember recognizing one of the problems as being related to the Bayesian Bootstrap, and I thought I had just nailed it. But when I had an opportunity to review my graded exam, the only marking 
on the page when I got it back was "9.5/10". Unable to resist asking the question, I went into Don's office soon after and conveyed that I was curious why I got 9.5/10. Without skipping a beat, Don said, "Oh, that's because at one point in Xiao-Li's answer, he wrote that such-and-such was obvious from a Bayesian perspective." And I thought, "I see-it wasn't that I did anything wrong, it was just that his answer was better!" I thought that was a good lesson, and I've shared the anecdote with many students over the years in situations where it is possible to do better.

You spent your summers during graduate school at the U.S. Census Bureau and Bureau of Labor Statistics, how did that come about and what were the implications on your career?

TB Part of the backdrop is that my initial interest in statistics grew out of a broader interest in public policy; also part of the backdrop is that I had spent a summer during college in Washington, DC and liked it very much. My first summer job at the Bureau of Labor Statistics in 1987 grew out of a tip from Don Rubin about people in Washington to contact. I would credit Nat Schenker, who went to the Census Bureau after studying with Don at the University of Chicago, with helping me get a job the next summer on the Census Bureau's Undercount Research Staff, which was led by Howard Hogan. I had met Nat when he gave a presentation in a seminar course Don was offering during my first year on statistical issues in census-undercount estimation, which is where I was first exposed to the computer matching problems that evolved into my Ph.D. thesis. During my first week at the Census Bureau, I ran a program to try to get a feel for the local computing environment and inadvertently used up all of the hard-drive space available for the entire Statistical Research Division, but on the whole, the job worked out well, and I was able to arrange a sequence of three straight summer jobs. Then, on my second day of work in the summer of 1990, at a time when the Census Bureau had to abruptly shift gears in response to a lawsuit to implement a prospective adjustment of the 1990 census that had not previously been planned, Howard Hogan greeted me and said something close to, "I think you should stay down here and work with us this year." For about 10 seconds I thought the idea was crazy, as I was planning to finish my Ph.D. thesis during the year. But then I thought it would be an amazing experience and that the job would not be there the next year, so in that moment I had the presence of mind to ask, "Could I have a day a week to work on my thesis?", and he responded without hesitation, "Yes." At that point, it was just a matter of getting Don on board, and he was fine with it too, so I spent that year working at the Census Bureau. It positioned me to be down in the trenches on a very high-profile problem at the interface of science and public policy and gave me an opportunity to get to know leading people in the profession who were working in the area, including people at the Census Bureau like Bob Fay, Bob Groves, John Thompson, Howard Hogan, Mary Mulry, Bill Bell, and Bill Winkler and people outside the Census Bureau like Steve Feinberg, Wayne Fuller, David Freedman, Ken Wachter, Don Ylvisaker, Bruce Spencer, Noel Cressie, William Kruskal, and Kirk Wolter.

Tell us about some influential work you did while in graduate school.

TB My thesis work on record linkage that was summarized in Belin and Rubin (1995a) estimating error rates by drawing on previous matching experience to fit mixture models, didn't get replicated a lot, but it did get recognized as an interesting idea that broke new ground, so articles in the record linkage literature frequently cite that work. The censusrelated project fitting a hierarchical logistic model to resolved post-enumeration-survey 
cases as a way to predict enumeration status for unresolved cases led to a 1993 JASA discussion paper (Belin et al. 1993) with Gregg Diffendal and Steve Mack of the Census Bureau as well as with Don Rubin, Joe Schafer, and Alan Zaslavsky helped frame discussion of the scientific merits of a proposed statistical adjustment to the census. And another project that started when I was in graduate school, which emerged as a prominent example in the Gelman, et al. series of "Bayesian Data Analysis" books and as a springboard for other research, involved analyzing repeated reaction times of schizophrenic and non-schizophrenic individuals where the schizophrenic reaction times were posited to come from a two-component mixture distribution to account for their greater variability. The article summarizing that work (Belin and Rubin 1995b) includes a lot of technical detail on applicable EM, ECM, SEM, and SECM algorithms, which might be finessed or bypassed in the $M C M C$ computing era in favor of an iterative simulation algorithm. But a part of the paper that still holds up well is the illustration of how posterior predictive checks could be used to help refine the mixture models to accommodate salient features of the data, and I still present that illustration to my own advanced students.

Meanwhile, before those papers were published, I think I was best known for a question I asked at the 1990 Joint Statistical Meetings to members of an advisory panel to the Secretary of Commerce, who was supposed to make a decision in the spring of 1991 on a possible statistical adjustment of the census. The panel had its origins in a lawsuit by large jurisdictions pressing for census adjustment and was comprised of four individuals identified by the plaintiffs and four chosen by the defendants. At the JSM session, with hundreds of people in attendance, William Kruskal, a choice of the lawsuit defendants, had offered damning criticism of proposed adjustment methods, while Eugene Ericksen, Kirk Wolter, and Leo Estrada, all choices of the plaintiffs, had offered damning criticism of an unadjusted census. During the floor discussion, after identifying myself, I asked Professor Kruskal what data he would need to see in order to favor adjustment, and I asked the other panelists what data they would need to see in order to oppose adjustment. The assembled audience immediately burst into a roaring applause-the discomfort I had felt about judgments being made without any reference to relevant data, which were still in the process of being collected, was clearly shared by others. That was a great moment for me, as I felt that I had taken a stand for science and that I was entering a profession with a great many kindred spirits.

\section{First few years at UCLA}

Can you describe your first position? Why did you choose it and whether there were other positions you were considering?

TB My first position at UCLA, starting in the fall of 1991, was as a postdoctoral researcher in the Department of Biomathematics. The back story of how this came to pass involves another small-world connection. Nat Schenker, who had helped me get my first summer job at the Census Bureau in 1988 and who had taken a job as an Assistant Professor in the UCLA Department of Biostatistics (I believe in 1989), called me early in 1991 to tell me that there was an opening for a post-doc at UCLA. Apparently, there had been a conversation in the background between Nat and Bob Elashoff, who eventually hired me, that set events in motion. 
Honestly, between the census production deadlines associated with my day job and my thesis work, which would typically occupy my evenings, not to mention my lingering Northern California bias from my time at Stanford and my comfort level with life on the East coast, I almost didn't bother pursuing the position because I was pretty sure I didn't want to live in Southern California. But my sister Joy lived in Los Angeles at the time, and I had other extended family in the area-I felt a bit guilty using the interview as an opportunity to spend time with family, but I thought if I flew out on Saturday, spent time with family over the weekend, and met with people at UCLA on Monday, I could take a break from the grind and only miss one regular workday by flying back on a red-eye flight Monday night and going to work Tuesday morning.

And then it turned into a really nice visit. I have often told the story of my job-talk dinner: the group included Weng Kee Wong, who had just started as an assistant professor and was the seminar coordinator, Bob Elashoff, Nat Schenker, Rod Little, my sister Joy (who had attended the presentation), and me. As people were milling around after the talk and there was a need to make a decision about where to go for dinner, and with no one else speaking up, Joy announced, "Well I like Soupplantation," which was down the street from where she lived in Brentwood. So that's where we went for my job-talk dinner.

Then, on the red-eye flight back to Washington, when I should have been sleeping, it turned out that the movie showing on the plane was "L.A. Story" starring Steve Martin playing a TV weatherman, with gags such as his being able to videotape his weather reports in advance since the weather is always the same in Los Angeles. Between the fact that the movie was so funny and that there was a plot line about his getting coded messages from the reader boards on the freeways, I remember having the thought that maybe the message to me was that I should really give some thought to coming out to L.A. for a couple of years. With one thing leading to another, that was now 29 years ago.

My position was great, incorporating a mix of interactions with health-science researchers and opportunities to interact with world-class statisticians. My office was next to Jeremy Taylor's, which afforded opportunities to connect. Rod Little organized a workgroup on longitudinal analysis, strengthened by the likes of Rob Weiss, Rob Kass (who was visiting while on sabbatical leave from Carnegie Mellon), and Marshall Joffe. I sensed that it would be important to learn something about statistical genetics, so I was able to sit in on Ken Lange's course. When it came time to decide what to do next and one of the options was to stay at UCLA, I limited my search and ended up staying.

At first, I had a non-tenure-track "in-residence" faculty position in Biostatistics, starting in 1993. The following year, after Don Guthrie retired from a position that was joint with the Department of Psychiatry and Biobehavioral Sciences, I applied for the resulting tenuretrack. opening and got that position in 1995, which was how I got extensively involved in mental-health research.

Then, in the 1998/1999 academic year, there was a search going on for a faculty position in biostatistics, while I was going up for tenure in Psychiatry. I was not originally a candidate for the Biostatistics position, but it reached a point where sometime in the spring, Dean [Abdelmonem] Afifi, who had been a mentor to me, called me and asked me to come down to the Dean's office. In the office with him was Bill Cumberland, then Chair of Biostatistics, and both told me they thought I should apply for the tenure-track position in Biostatistics and move my primary appointment there. I was nervous at first about how 
the Psychiatry people would react, but they couldn't have been more gracious about it, and it turned out well because I was able to stay connected to Psychiatry with a joint appointment after moving to Biostatistics.

How did you become involved in the HPSS and ICHPS?

TB I believe it was in that period when HPSS emerged as a new section. Alan Zaslavsky had been a mentor to me, first while he was finishing his Ph.D. studies and then when he became an Assistant Professor in the Harvard Statistics Department. Sharon-Lise Normand had been a post-doc with Carl Morris, who joined the Harvard Statistics Department while I was there, and I thought it was great when the Department of Health Care Policy in Harvard Medical School hired Sharon-Lise and Alan to anchor their statistical research efforts. I think my first formal involvement in HPSS was being asked (for the sake of satisfying ASA rules for there to be a competitive election for section chair) to be the losing candidate when Sharon-Lise was running to be HPSS Chair (an outcome I endorsed with my vote).

I did not attend the first conference in the ICHPS series, but having attended all of the ensuing ICHPS meetings, I was asked somewhere along the way, I don't recall by whom, whether I would be open to co-chairing the 2005 meeting with Arlene Ash. I had known Arlene on a "hi-how-are-you" basis for many years, as she would often join for seminars at Harvard from her position across the river at Boston University, but I didn't know her very well prior to co-chairing the 2005 meeting. I was pleased to say "yes", as it seemed like a great opportunity, and in the process, she and I hit it off and have been close ever since.

What is the favorite paper you have been involved in? Or the one that you are the most proud of?

TB That is hard. I'm going to not name a favorite one, but a set of papers that are meaningful. One was this paper on the Census Bureau work that included Joe Schafer, Don Rubin, Alan Zaslavsky, Gregg Diffendal, and Steve Mack (Belin et al. 1993). I felt like that one helped launch my work into more sophisticated methods. The two others I mentioned from my graduate study, both with Don Rubin (Belin and Rubin (1995a), JASA paper on record linkage and Belin and Rubin (1995b), Statistics in Medicine paper on mixture models for schizophrenic reaction times), really helped me understand incomplete-data methods and posterior predictive checks, and I've referred to them a lot in my teaching.

One other paper that stands out from earlier in my career is on DNA identification. I had been sitting in on Ken Lange's course on statistical genetics, and he was giving a presentation on forensic DNA applications, where he had presented a method for relaxing reliance on gene-frequency databases in calculating match probabilities, and as a headstrong post-doc I had said, "No, no, no, that's all wrong-the defense lawyers will pick on you for any conditional independence assumption-you should use a distance metric on the distance between the bands on these assays and finesse the independence assumption." I think he was a bit startled by my soapbox declaration, but Ken's thoughtful response was, "Well, write it up!" It took a while, but I worked with David Gjertson, who had access to genetic paternity data, and my student Ming-yi Hu, and we did write it up. Along the way, while that paper was in pre-print form, the O.J. Simpson trial was going on, and Bob 
Elashoff encouraged me to send the paper to Judge Lance Ito of the court, which I did. In my files somewhere, I have a reply letter from Judge Ito saying he'd give the paper to both the prosecution and the defense. We first submitted the paper to the American Journal of Human Genetics, and although the comments were mostly vaguely positive, the paper was rejected on the grounds that it didn't make any use of genetics theory. But that was exactly the point! So we sent pretty much the same paper to JASA Theory and Methods (Belin et al. 1997), and they loved it because it didn't make any use of genetics theory.

I should also mention, in addition to your dissertation papers (Zigler and Belin 2011, 2012), Cory, that one other paper I'm especially proud of is the paper we worked on with Heidi Fischer developing density-variation/compactness scores for evaluating redistricting plans (Belin et al. 2011). It's far from among my most cited papers at this point, but I still think of the idea as having merit and as having great potential to be influential, and I see myself doing something with it during the next round of redistricting that's coming up.

It seems that you know "Everyone"- - how has that helped/hindered your career and/or dayby-day life?

TB Your question led me to think a lot about this, as there's a reality to my knowing a lot of people, and I think a combination of factors are involved. Part of it is just that I've had a variety of experiences within the field. Even in that short history of my positions at UCLA, I was building up networks deliberately, and I was able to maintain those networks when I moved to a new position. I had a summer job at the Bureau of Labor Statistics where there were a lot of statisticians, a summer job at the Census Bureau where there were a lot of statisticians, and those networks grew. And then there's the cast of characters in my graduate school program: Andrew Gelman, Xiao-Li Meng, Joe Schafer, Alan Zaslavsky, Chris Schmid, which grounded me with a great group of friends. And then there are the connections through faculty. As a graduate student, I met Nat Schenker and Rod Little during their respective visits during in my first year, and I had opportunities to meet Neil Thomas and Dan Heitjan, who were students of Don [Rubin] at the University of Chicago. Oh, and the opportunity to connect with Raghu [T. E. Raghunathan], Hal Stern, and John Carlin, who taught us Bayesian statistics-I remember Andrew borrowed my course notes from John Carlin's class when he was first working on the Bayesian Data Analysis textbook, as back in the day, Andrew rarely took notes, and I was known for annotating my notes with narrative transitions to make them easier to read afterward. Another opening that comes to mind is being one of not too many people who knew how to use Joe Schafer's missing data software before his book came out (Schafer 1997), which helped me establish myself as a missing-data guy.

I also think there are personality factors of being curious and playful and enjoying spending time with other people. I think my being engaged in the community is a factor. And some of it is just that I have a lot of connections through my family: for example, when I spoke at Penn State early in my career, Joe Schafer introduced me saying, "One thing you need to know about Tom is that he knows Monty Hall." The story on that is that my father knew him, and my sister and I were invited over to his house soon after I moved to L.A.

I thought your choice of words was interesting, as I accept that there are ways that "knowing everyone" can hinder things. I think of myself as having an "open-door personality", and I've found that if I have an "open-door policy" at the office, which is in a well-traveled 
corridor, then I often don't get anything done. When I was an assistant professor, I had become an associate editor for three journals: Journal of Educational and Behavioral Statistics, Journal of Official Statistics, and Evaluation Review. When I was going up for my 4th year appraisal for early academic-personnel feedback, it wasn't uniformly positive, and one of the criticisms I received was along the lines of "his service work is almost too strong" or something like that. And I got the message, counting it as a learning experience that I should spend more time on research publications and transitioning out of those associate-editor roles soon after.

\section{Mentoring}

As one of your mentees, I'm curious whether you have a general philosophy of mentoring, or where mentoring fits in the priority list of someone in your role?

TB I think I would say that I didn't have a grand philosophy but that I've developed one as I've gained experience. I was working from the model of what things were like in the Harvard Statistics Department. I remember being scared when they would talk about the qualifying exam covering "all of statistics" when at the same time they would typically offer only a few courses. As a first-year student, at a social gathering before a seminar, I decided to raise the issue with Art Dempster, who had initially been assigned to be my advisor. To convey the point, I noted that the course listed in the handbook on experimental design hadn't been taught in years and that there should be a course taught on experimental design if we were expected to know it for the qualifying exam. He looked at me kind of quizzically and responded, "You can't read a book?" I thought "Oh, I get it" like it was part of my orientation and that it isn't all going to be handed to you on a silver platter. And to me there was something valuable in that "kick in the pants" that I'd relate to mentorship, as an important role for a mentor is to help you to learn to fly solo. So, I do think there's a role for that.

I think of learning statistics as kind of like language acquisition in kids. You start with immersion, and then you fill in the gaps. The kind of education that goes at the level of an apprenticeship in graduate school is so non-linear. People struggle, struggle, struggle, and then, ideally at least, there's like a light bulb moment when the world opens up. I've often rebelled against a checklist model for graduate education, because I don't think it can capture what learning is like in graduate school.

What about your life outside of work? What do you like to do?

TB That certainly brings to mind my family, which is hard because I'm recently divorced after 22 years of marriage to a faculty member in the School of Medicine at UCLA [Anne Coleman] who was a student of Sander Greenland in Epidemiology at the time we met, which led one of my college friends to say that this academic thing finally had paid off for me. Our daughter Janet [Coleman-Belin] is a big focus of my world. She finished college last June and is in a gap year, scheduled to start medical school in the fall, which before being disrupted by the coronavirus epidemic had included a wonderful mix of travel and volunteer experiences. Another thought that comes to mind is having served as the PTA President at Janet's elementary school. It was like running a small nonprofit organization. 
I had started out as one of the Co-Recording Secretaries, taking minutes at half of the meetings. I don't know if it was because my minutes read like hours, but a couple years later I got asked to be the President. I didn't think I'd be able to do it, but said I would if they could find a Co-President. They did, although about a year into a two-year term, the Co-President dropped out. Still, those were great experiences. It was demanding at times, but I am proud of that involvement, and I feel that plugging in the way I did, which included increasing the PTA budget by a six-figure amount to support a reading specialist and to cover for other funding cuts, had a meaningful impact on the school and on the community. In my down time you'll also find me reading, listening to music, going to farmers markets, on a good day going for a short run or a long walk, and thinking about ways to make the world a better place.

\section{Conclusions}

Dr. Tom Belin's accomplishments are too many to count, the number of students, colleagues and mentees that will be happy to praise him is longer than we can mention. We are confident Tom will continue producing influential research via papers and grants. There are many more students and mentees who will be lucky to be mentored by Tom. If you attend statistical conferences, there is a good chance you will cross his path and you can hear his roaring laugh and his beaming personality.

\section{References}

Belin, D.W.: November 22, 1963: You Are The Jury. Quadrangle/The New York Times Book, New York (1973)

Belin, D.W.: Final Disclosure: The Full Truth About the Assassination of President Kennedy. Charles Scribner's Sons, New York (1988)

Belin, T.R., Rubin, D.B.: A method for calibrating false-match rates in record linkage. J. Am.Stat.Assoc. 90(430), 694-707 (1995a)

Belin, T.R., Rubin, D.B.: The analysis of repeated-measures data on schizophrenic reaction times using mixture models. Stat. Med. 14(8), 747-768 (1995b)

Belin, T.R., Diffendal, G.J., Mack, S., Rubin, D.B., Schafer, J.L., Zaslavsky, A.M.: Hierarchical Logistic regression models for imputation of unresolved enumeration status in undercount estimation. J. Am. Stat. Assoc. 88(423), 1149-1159 (1993)

Belin, T.R., Gjertson, D.W., Hu, M.-Y.: Summarizing DNA evidence when relatives are possible suspects. J. Am. Stat. Assoc. 92(438), 706-716 (1997)

Belin, T.R., Fischer, H.J., Zigler, C.M.: Using a density-variation/compactness measure to evaluate redistricting plans for partisan bias and electoral responsiveness. Stat. Politics Policy 2 (1), (2011)

Belin, T.R., Jones, A., Tang, L., Chung, B., Stockdale, S.E., Jones, F., Wright, A., Sherbourne, C.D., Perlman, J., Pulido, E.: Maintaining internal validity in community partnered participatory research: experience from the community partners in care study. Ethn. Dis. 28(Suppl 2), 357 (2018)

Bisher, F.: Strange But True Baseball Stories. Random House, New York (1966)

Gelman, A., Carlin, J.B., Stern, H.S., Dunson, D.B., Vehtari, A., Rubin, D.B.: Bayesian Data Analysis. CRC Press, Boca Raton (2013)

Little, R.J.A., Rubin, D.B.: Statistical Analysis with Missing Data, vol. 793. Wiley, Amsterdam (2019)

Rubin, D.B.: Multiple Imputation for Nonresponse in Surveys, vol. 81. Wiley, Amsterdam (2004)

Schafer, J.L.: Analysis of Incomplete Multivariate Data. Chapman and Hall/CRC Press, New York (1997)

Shetty, V., Atchison, K., Leathers, R., Black, E., Zigler, C., Belin, T.R.: Do the benefits of rigid internal fixation of mandible fractures justify the added costs? Results from a Randomized controlled trial. J.Oral Maxillofac. Surg. 66(11), 2203-2212 (2008)

Wells, K.B., Jones, L., Chung, B., Dixon, E.L., Tang, L., Gilmore, J., Sherbourne, C., Ngo, V.K., Ong, M.K., Stockdale, S.: Community-partnered cluster-randomized comparative effectiveness trial of 
community engagement and planning or resources for services to address depression disparities. J. Gen. Intern. Med. 28(10), 1268-1278 (2013)

Zigler, C.M., Belin, T.R.: The potential for bias in principal causal effect estimation when treatment received depends on a key covariate. Ann. Appl. Stat. 5, 1876-1892 (2011)

Zigler, C.M., Belin, T.R.: A Bayesian approach to improved estimation of causal effect predictiveness for a principal surrogate endpoint. Biometrics 68, 922-932 (2012)

Zima, B.T., Bussing, R., Tang, L., Zhang, L., Ettner, S., Belin, T.R., Wells, K.B.: Quality of care for childhood attention-deficit/hyperactivity disorder in a managed care medicaid program. J. Am. Acad. Child Adolesc. Psychiatry 49(12), 1225-1237 (2010)

Publisher's Note Springer Nature remains neutral with regard to jurisdictional claims in published maps and institutional affiliations. 